STAATSRECHT: Indonesian Constitutional Law Journal Volume 5 Nomor 1 (2021). P-ISSN: 2549-0915. E-ISSN: 2549-0923

THE BOGOR REGENCY REGIONAL PEOPLE'S REPRESENTATIVE

COUNCIL'S LEGISLATIVE FUNCTION IN THE PREPARATION OF REGIONAL REGULATIONS 


\title{
The Bogor Regency Regional People's Representative Council's Legislative Function in the Preparation of Regional Regulations*
}

\author{
M. Syaiful Azhar ${ }^{1}$ Mufidah $^{2}$ \\ Institut Agama Islam Al-Zaytun Indonesia (IAI AL-AZIS) \\ $\underline{10.15408 / \text { siclj.v5i1.20752 }}$

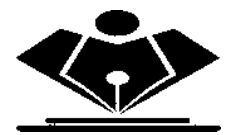

Abstract

The legislative function of the DPRD has not run smoothly. In some areas still experiencing various problems. This study aims to determine the implementation of the legislative function of DPRD in Bogor City in 2013-2018. This study uses a qualitative method with a literature approach. The data of this study were obtained from binding legal materials consisting of legislation, policy considerations of the political elite, namely the Bogor City Regional House of Representatives, books, and legal journals. The results of this study state that the legislative function carried out by the DPRD of Bogor City is in accordance with Law Number 23 of 2014 concerning Regional Government, one of which is the function of legislation to capture the aspirations of the people in the City of Bogor, namely by receiving reports or complaints from the people of the City of Bogor on problems. for dissatisfaction with a service. However, the implementation is still not optimal because there are still obstacles in carrying out legislation.

Keywords: DPRD, Legislation Function, Regional Regulation

* Received on March 19, 2021, reviewed on May 4, 2021, Published on June 18, 2021.

${ }^{1}$ M. Syaiful Azhar is a Student of Constitutional Law Study Program. Fakultas Syariah Institut Agama Islam Az-Zaytun tahun 2020, alamat email:msaipulashar82@gmail.com

2 Mufidah is a Lecturer in Institut Agama Islam $\mathrm{Al}$ Zaytun Indonesia, Mekarjaya, Gantar, Indramayu, Jawa Barat, alamat email: mufidah@iaialzaytun.ac.id 


\section{A. INTRODUCTION}

An independent and sovereign state was formed with the same mission, namely to build a more prosperous life together. The preamble to the 1945 Constitution states that the purpose of the establishment of the Unitary State of the Republic of Indonesia (NKRI) is to protect citizens and the territory of the state, as well as to promote general welfare (Ashiddiqie, 1999). The State of Indonesia is a unitary state that adheres to the principle of decentralization in the administration of government. This can be seen from the provision of opportunities and flexibility to regions to carry out Regional Autonomy which is carried out by regional governments or in other words regions are given the freedom to manage their own government affairs. As stated in Article 18 paragraph (2) of the 1945 Constitution of the Republic of Indonesia, which reads: "Provincial, Regency and City regional governments regulate and manage their own government affairs according to the principle of autonomy and co-administration." (See: 1945 Constitution of the Republic of Indonesia Article 18 paragraph (2).

According to the amendments to the 1945 Constitution, the power to administer the state is no longer centered on the President. This is at least marked by the President no longer having the power to make laws, but the DPR. In this case, the President only proposes a draft law. Likewise in local government, DPRD has more authority to make laws than regional heads.

Since the enactment of Law no. 22 of 1999 concerning the Principles of Regional Government, there has been a paradigm shift at the level of formation of regional laws and regulations. The most prominent shift is the shift in the focal point of the authority to form laws from the executive to the legislature. This Law has regulated the principles/principles of the administration of regional government, especially the relationship of authority between the DPRD and the Regional Head with a new paradigm, 
namely democratization of regional government administration. This includes the issue of the authority to form laws.

Law Number 22 of 1999 caused many irregularities, including uncontrolled regionalism, politicization of government officials, arrogance of DPRD institutions, unequal regional financial legislation and imbalance of authority between DPRD and Regional Heads in the preparation of Regional Regulations (Suandi; Hamid; Sobirin, 2004). The number of disparities, then in 2004 Law no. 22 of 1999 was replaced by Law no. 32 of 2004 concerning Regional Government. This law provides an equal share between the Regional Head and the DPRD in terms of legislative authority (See: Law No. 32 of 2004 concerning Regional Government). To address these problems, changes were made, especially those relating to the regulation on the implementation of regional head and deputy regional head elections, as outlined in Law of the Republic of Indonesia Number 8 of 2005 concerning Stipulation of Government Regulations in Lieu of Law Number 32 of 2004 concerning Regional Government becomes law. Then the second amendment to Law Number 32 of 2004 was also stipulated with the enactment of Law of the Republic of Indonesia Number 12 of 2008 concerning the Second Amendment to Law Number 32 of 2004 concerning Regional Government (Rosidin, 2009).

Regional legal products are not the monopoly of the Regional Head. Article 40 of Law Number 12 of 2008 concerning the Second Amendment to Law Number 32 of 2004 concerning Regional Government states that DPRD is a regional people's representative institution and is domiciled as an element of regional government administration. One of the tasks and powers of the DPRD is to establish a regional regulation which is discussed with regional heads for mutual approval as stated in Article 42 paragraph (1) letter a of Law Number 12 of 2008 concerning Amendments to Law Number 32 of 2004 concerning Regional Government. Based on these duties and authorities, it is possible for the DPRD to submit a draft regional regulation to the regional head for joint discussion. The submission of a draft 
regional regulation by the DPRD can be done at the proposal of DPRD members which is then approved by the DPRD plenary meeting. However, in reality there are still DPRD members who lack adequate knowledge and understanding so that the function of legislation is not optimal.

The improvement of the legislative function or the regulatory function of the DPRD is not only seen from the regulations produced, which come from the DPRD's initiative rights. The quality of the DPRD in carrying out its functions is also measured by the content of regional regulations which should be more focused on the interests of the wider community. In the preparation of regional regulations, DPRD members must play more of a role as a source of ideas and ideas, according to their position as political people. DPRD members are not required to technically master the material and legal language of regional regulations, because this can be left to experts in their respective fields. Existing local government practices often illustrate how DPRD members are busy drafting regional regulations to very detailed and substantive matters, without being based on sufficient expertise. In the end what emerged was a prolonged debate about something by those who both did not understand the substance, so that they spent time without being able to resolve it properly (Waistiono; Wiyoso, 2010).

Indications that the legislative function of the DPRD is not optimal can be seen from the quantity and quality of legal products produced by the Regional Government. In terms of quantity, there are not many new regulations that are oriented towards the welfare of the people. Regional Heads and DPRD are still struggling with old Regional Regulations that need to be revised and adapted to current conditions, but are barren in producing new legal products.

Another indication that the legislative function of the DPRD is not optimal is the DPRD's lack of initiative in submitting draft laws. The regional regulations produced by the regional government are mostly the initiative of the regional head (Prakoso, 1995). Meanwhile, the DPRD only urun rembug 
the proposed law and participates in ratifying it, so that the legislative function of DPRD members is seen as unsatisfactory to the public. The above phenomenon illustrates that the competence of board members in the field of law and legislation is weak.

Indeed, there are many challenges that must be faced by the DPRD in carrying out its functions, including the situation and conditions of the region, the internal weaknesses of the DPRD and the conflict of interest between the central authority that has not been delegated and the obligation to bring the aspirations of the regional people. It seems that challenges like this need to be solved proportionally, so that the DPRD can be aspirational to the demands of the people and supportive of national policies.

In its development, the legislative function of DPRD has not run smoothly. In some areas still experiencing various problems. For example, in Semarang City, of the 12 Regional Regulation Meetings (Raperda) that were entered in the DPRD all came from executive initiatives and at the end of 2006 the Semarang City DPRD used more budgeting and legislative rights, even though it was hoped that the council could submit a RAPERDA on the initiative of the legislature so that it would not rely solely on the RAPERDA from the executive.

Bogor Regency which is used as the location of this research is one of the regencies that has a large population. Based on data from the Central Bureau of Statistics (BPS) of Bogor Regency, the population of Bogor Regency based on the 2017 Final Registration Results reached 5,715,0009 people (www.bogorkab.bps.go.id). Such a situation results in the high level of heterogeneity that will indirectly affect the course of government administration to become more complex and dynamic. This situation will trigger control from the community, non-governmental organizations (NGOs), and DPRD on the implementation of local government so that it can run efficiently, effectively, and well in accordance with the wishes of the whole community. 
The Bogor Regency DPRD as part of the Bogor Regency local government administration also participates in realizing good governance by increasing its role and function in government, namely in implementing policies for making regional regulations. The role of DPRD is very large in regional government because it is a regional legislative body that functions as one of the institutions for channeling the aspirations of the people in the region. One of the functions of the Bogor Regency DPRD as a regional representative institution is the legislative function. This function is even often referred to as the core of a representative institution, namely as a law-making body within the scope of the region.

From the description above, the researcher is interested in carrying out a research entitled "The Legislation Function of the Bogor Regency Regional People's Representative Council in the Preparation of Regional Regulations for 2013-2018". The main problem that is the focus of discussion in this study is related to the role of the legislative function of the DPRD. To emphasize the direction of the discussion of the main problems that have been stated above, the researchers formulate the problem as follows: How is the implementation of the legislative functions of the Bogor City DPRD in 2013-2018?

\section{B. METHODS}

This study uses a qualitative method with a literature approach. The type of research used in this research is normative legal research. This research data was obtained from primary legal materials, namely legal materials that have authority (Ali, 2010). The legal material consists of legislation, especially the Law on the Establishment of Legislation, political elite policy considerations, namely the Bogor City Regional House of Representatives, books, and legal journals. 


\section{RESULTS AND DISCUSSION}

\section{Definition of DPRD}

The Regional People's Representative Council (DPRD) according to Article 1 point (4) of Law Number 23 of 2014 concerning Regional Government is a regional people's representative institution and is domiciled as an element of regional government administration. The DPRD consists of members of political parties participating in the general election who are elected through general elections. Provincial DPRD is a provincial people's representative institution that is domiciled as an element of provincial government administration, while Regency/Municipal DPRD is a regional people's representative institution that is domiciled as an element of regency/city regional government administrator (Moenta, 2018: 67).

\section{The Role and Functions of DPRD}

The function of the Regency/City DPRD is regulated in Law Number 23 of 2014 Article 149 paragraph (1), namely:

First; Function of Establishment of Regency/City Regional Regulations. In the function of forming regional regulations, DPRD places a very strategic and honorable position, because DPRD participates in determining the sustainability and future of the region. This must also be interpreted as a mandate to fight for and improve their welfare. The function of the formation of regional regulations is a process to accommodate the various interests of the stakeholders, to determine how development in the regions will be carried out. This function has a very important meaning to create the desired state of society and as a creator of social justice for the community (Waistiono; Wiyoso, tth: 54). The purpose and benefits of this function are to provide a solution together with the government to develop a legal umbrella that can solve certain problems (Law No. 23 of 2014 Article 149 paragraph (1)).

Second; Oversight function. In the supervisory function, 
the DPRD oversees the implementation of district/city regulations and regent/mayor regulations, oversees the implementation of other laws and regulations related to the administration of district/city Regional Governments and supervises the implementation of follow-up on the results of the audit of financial statements by the State Audit Board. This legislation aims to develop democratic life, guarantee the representation of the people and regions in carrying out their duties and authorities, and develop checks and balances between the legislative and executive institutions in order to realize justice and people's welfare (Wasistiono, $t$ th: 143).

Third; Budgeting Function. In this budget function, it has a very important role in realizing people's welfare and increasing competitiveness. This function is also a planning tool to formulate policy goals and objectives in accordance with the vision and mission set, as a tool for government fiscal policy used to stabilize and encourage economic growth. (Law No. 23 of 2014 Article 149 paragraph (1)).

\section{Duties and Authorities of DPRD}

Provincial DPRD has the duties and authorities based on Article 101 paragraph (1) of Law Number 9 of 2015 concerning the Second Amendment to Law Number 23 of 2014 concerning Regional Government are: (Law No. 9 of 2015 article 101 paragraph (1)) .

a) To form a provincial regulation with the governor;

b) Discussing and approving the draft provincial regulation on the provincial APBD submitted by the governor;

c) Implementing legislation on the implementation of provincial regulations and provincial budgets;

d) To elect governors and deputy governors in the event of a vacancy in office to continue the remaining term of office;

e) Propose the appointment and dismissal of the governor to 
the president through the minister to obtain approval for the appointment and/or dismissal;

f) Provide opinions and considerations to the provincial government on the international agreement plan in the province;

g) Giving approval to the international cooperation plan carried out by the provincial regional government.

Regency/city DPRD has the duties and authorities regulated in Article 154 paragraph (1) of Law Number 9 of 2015 concerning the Second Amendment to Law Number 23 of 2014 concerning Regional Government, namely: (Law No. 9 of 2015 article 154 paragraph (1))

a) Forming district/municipal regulations together with regents/mayors;

b) Discussing and approving the draft district/municipality regional regulation on the district/city APBD submitted by the regent/mayor;

c) Implement legislation on the implementation of district/city regulations and district/city APBD;

d) Selecting the regent and deputy regent as well as the mayor and deputy mayor in the event of a vacancy in office to continue the remaining positions;

e) Propose the appointment and dismissal of the regent/mayor to the minister through the governor as the representative of the central government to obtain approval for the appointment and/or dismissal;

f) Provide opinions and considerations to the district/city regional government on the international agreement plan in the regency/city area;

g) Give approval to the international cooperation plan carried out by the district/city regional government;

h) Request a report on the accountability of the regent/mayor 
in the administration of the regency/city regional government;

i) Approval of plans for cooperation with other regions or with third parties that burden the community and districts/cities.

\section{Rights and Duties of DPRD members}

Provincial DPRD and Regency/Municipal DPRD have rights as regulated in Article 106 paragraph (1) of Law Number 23 of 2014 concerning Regional Government as follows:

First; Interpellation, the right of the Provincial DPRD and Regency/Municipal DPRD to request information from the regional head regarding policies of the provincial government and regency/city government that are important and strategic and have a broad impact on the life of society and the state.

Second; Questionnaire, the right of the Provincial DPRD and Regency/Municipal DPRD to conduct investigations on policies of the provincial government and regency/municipal governments that are important and strategic and have a broad impact on the lives of the people, regions and the state which are suspected to be contrary to the provisions of the legislation.

Third; Express opinions, the right of the Provincial DPRD and Regency/Municipal DPRD to express opinions on the policies of the regional head or regarding extraordinary events that occurred in the province and/or regency/city areas accompanied by recommendations for their resolution or as a follow-up to the implementation of the right of interpellation and the right of inquiry.

Each member of the provincial and district/city DPRD has the right, namely: a) The right to submit draft regional regulations; b) The right to ask questions (interpellation); c) The right to convey a proposal and opinion freely both to the regional government and to the DPRD, so that there is a guarantee of independence in accordance with the call of conscience and its 
credibility; d) The right to vote and be elected; e) The right to selfdefense; f) Immunity rights; g) The right to participate in the orientation and deepening of tasks; h) Protocol rights; i) Financial and administrative rights.

The obligations of members of the provincial and district/city DPRD are: a). Uphold and practice Pancasila; b). Implement the 1945 Constitution of the Republic of Indonesia and comply with the provisions of laws and regulations; c). Maintain and maintain national harmony and the integrity of the Unitary State of the Republic of Indonesia; d). Prioritizing the interests of the state above personal, group and class interests; e). Fight for the improvement of people's welfare; f). Adhering to the principles of democracy in the administration of Regional Government; g). Obey the rules and code of ethics; h). Maintain ethics and norms in working relations with other institutions in the administration of provincial government; i). Absorb and collect constituent aspirations through regular working visits; j). Accommodating and following up on public aspirations and complaints; and k). Provide moral and political accountability to constituents in their constituencies.

\section{Legislation Scope of DPRD}

The functions of legislation include::

1) Function to form regional regulations (Perda) with regional heads (DPRD is a policy maker, not a policy implementer);

2) A strategic function that places the DPRD as a "respectable institution" in developing trust and fighting for the aspirations of the people;

3) It is a "struggle function" to determine the sustainability and future of the region;

4) It is a process to accommodate the various interests of the parties/stakeholders (according to the Indonesian Legislation Process Information Center). 


\section{Bogor Regency DPRD Overview}

Bogor Regency has 6 sub-districts, 68 sub-districts. With the existence of Law Number 23 of 2014 concerning Regional Government, which focuses on regional autonomy in regencies/cities, there is a shift in the pattern of government from a centralized pattern to a decentralized pattern. DPRD and regional heads are located as elements of regional government administrators who are mandated to carry out government affairs that are handed over to the regions. Thus, the DPRD and regional heads act as equal partners with different functions.

One of the important steps in the journey of an organization is the determination of the Vision which is part of strategic planning which is essentially the future capital that must be shared and used by all members of the organization.

\section{Bogor Regency DPRD Vision and Mission}

Based on the vision of Bogor Regency, namely "The Realization of a God-fearing, Empowered and Cultured Bogor Regency Community Towards Prosperity", and paying attention to the mission, direction and strategy of Bogor Regency policies by paying attention to West Java Province policies, and referring to National policies in the implementation of extensive Regional Autonomy, Real and responsible, and in the context of community empowerment, the Bogor Regency DPRD Secretariat Vision has been formulated, namely "The Realization of Excellent Service in Facilitating the Implementation of the Roles and Functions of the Bogor Regency DPRD towards the most developed Regency in Indonesia."

The Vision Statement above means, namely:

1. Assist the Regent's duties in administering secretarial administration, financial administration in supporting the implementation of the duties and functions of the DPRD;

2. The achievement of excellent service in facilitating the 
role and function of the Bogor Regency DPRD;

3. Supporting the vision of Bogor Regency towards Bogor Regency to become the most developed Regency in Indonesia.

Mission Statement:

Based on the Vision and Mission of the Bogor Regency for 2013-2018 and the Vision of the DPRD Secretariat, the main tasks and functions of the DPRD Secretariat as well as inputs from interested parties (stakeholders), the Mission of the Bogor Regency DPRD Secretariat is set as follows: (http://setwan.bogorkab.go.id/visi-dan-misi/).

1). First Mission: "Improving Apparatus Professionalism." This mission contains the goal of fulfilling the quality of professional apparatus who have a coordinating, communicative and participatory spirit in accordance with the demands of the main tasks and functions of each section, so that the performance of the administration of government is increased.

2). Second Mission: "Improving Administrative and Managerial Services through optimizing the implementation of the DPRD Secretariat's main tasks and functions." This mission implies the realization of professional and accountable financial administration, facilities and infrastructure, staffing and correspondence so as to create government administration at all levels that is transparent, accountable, efficient, participatory, clean and authoritative and continues to prevent corruption (http://setwan.bogorkab.go.id/visi-dan-misi/).

The membership of the Bogor City DPRD is divided into 4 Commissions, namely: (http://setwan.bogorkab.go.id/visi-danmisi/)

1. Commission I for Law and Governance, covering Government, Security, Order, Peace, Information/Press, Public Relations, Law/Legislation, Civil Service/Apparatus, Social, Politics, Community 
The Bogor Regency Regional People's Representative Council's Legislative Function in the Preparation of Regional Regulations

Organizations, Land Affairs, Licensing and Fire Fighting.

2. Commission II for Development, covering Market Development, Agriculture, Plantation and Food Crops, Livestock and Fishery, Transmitter Tower, Highways, Water Management, Utility Network Facilities, Environment, Transportation and Transportation, Mapping and Spatial Planning, Public Street Lighting, Development and Hygiene and Gardening Legislation.

3. Commission III for Economics and Finance, covering Regional Finance, Taxation, Levies, Banking, Regional Companies, Management Agency, Empowerment of Regional Assets and Wealth, Mining and Energy, Joint Ventures/Business World/Foundations, Investment, Trade.

4. Commission IV for People's Welfare; covering religion, Education, Health, Science and Technology, Tourism, Arts and Culture, Women's Empowerment and Family Planning, Youth and Sports, Social Affairs, Manpower and Transmigration.

\section{Optimizing the Legislation Function of the Regional House of Representatives (DPRD) of Bogor City for the 2013-2018 Period}

In carrying out the legislative function, what the DPRD does is in accordance with the aspirations expressed by the community. Basically, community leaders have an important role in the implementation of local government activities in Bogor City, because community leaders have a close emotional bond with the community, so to accommodate various ideas for the benefit of the community, community leaders are expected to be able to absorb every policy of local government administrators.

Basically the legislation carried out by the Bogor City 
DPRD is a very important part in the administration of government, without this function, the power of a country will run according to the will of the ruler.

There are 54 Bogor City Regional Regulations in 20132018, including the following:

1. Regional Regulation Number 2 of 2013 concerning Diniyah Takmiliyah Education..

2. Regional Regulation Number 3 of 2013 concerning the Implementation of Road Traffic and Transportation.

3. Regional Regulation Number 4 of 2013 concerning Accountability for Implementation of Regional Revenue and Expenditure Budgets for Fiscal Year 2012.

4. Regional Regulation Number 5 of 2013 concerning Bogor City Regional General Hospital.

5. Bogor City Regional Regulation Number 1 of 2013 concerning Regional Revenue and Expenditure Budget for Fiscal Year 2013

6. Bogor City Regional Regulation Number 6 of 2013 concerning Changes in the Regional Budget for Fiscal Year 2013.

7. Bogor City Regional Regulation Number 7 of 2013 concerning Regional Revenue and Expenditure Budget for Fiscal Year 2014.

8. Regional Regulation of the City of Bogor Number 8 of 2013 concerning Regional Equity Participation in Regional Companies of Pasar Pakuan Jaya, Bogor City.

9. Regional Regulation Number 1 of 2014 concerning Environmental Protection and Management.

10. Regional Regulation Number 2 of 2014 concerning Drinking Water Services for Tirta Pakuan Regional Drinking Water Company, Bogor City.

11. Regional Regulation Number 3 of 2014 concerning the Organization and Work Procedure of the Bogor City Regional Disaster Management Agency.

12. Regional Regulation Number 4 of 2014 concerning Amendments to Regional Regulation of Bogor City 
Number 3 of 2010 concerning Organization of Regional Apparatus.

13. Regional Regulation of the City of Bogor Number 6 of 2014 concerning the Medium-Term Development Plan of the City of Bogor for 2015-2019.

14. Bogor City Regional Regulation Number 5 of 2014 concerning Accountability for the Implementation of the Regional Revenue and Expenditure Budget for the 2013 Fiscal Year.

15. Bogor City Regional Regulation Number 7 Concerning Changes in Regional Revenue and Expenditure Budgets for Fiscal Year 2014.

16. Bogor City Regional Regulation Number 8 concerning Amendments to Bogor City Regional Regulation Number 4 of 2012 concerning Public Service Retribution.

17. Bogor City Regional Regulation Number 9 of 2014 concerning Regional Revenue and Expenditure Budget for Fiscal Year 2015.

18. Bogor City Regional Regulation Number 10 of 2014 concerning Road Operations.

19. Regional Regulation of the City of Bogor Number 7 of 2015 concerning Amendments to Regional Regulation of the City of Bogor Number 8 of 2013 concerning Regional Equity Participation in Regional Companies of Pakuan Jaya Market, Bogor City.

20. Regional Regulation Number 11 of 2015 concerning Regional Equity Participation in Bogor City Transportation Service Companies.

21. Bogor City Regional Regulation Number 4 of 2015 concerning Amendments to Bogor City Regional Regulation Number 16 of 2008 concerning the Implementation of Population Administration.

22. Bogor City Regional Regulation Number 1 of 2015 concerning the Implementation of Advertisements.

23. Regional Regulation Number 2 of 2015 concerning Amendments to Regional Regulation of Bogor City 
Number 13 of 2012 concerning Management and Implementation of Education.

24. Regional Regulation Number 3 of 2015 concerning Legal Aid for the Poor.

25. Regional Regulation Number 8 of 2015 concerning Regional Equity Participation to Regional Water Company Tirta Pakuan Bogor City.

26. Bogor City Regional Regulation Number 5 of 2015 concerning Accountability for the Implementation of the Regional Revenue and Expenditure Budget for the 2014 Fiscal Year.

27. Bogor City Regional Regulation Number 6 of 2015 concerning Amendments to Bogor City Regional Regulation Number 7 of 2006 concerning Buildings.

28. Bogor City Regional Regulation Number 9 of 2015 concerning Amendments to Bogor City Regional Regulation Number 6 of 2012 concerning Certain Licensing Retribution.

29. Bogor City Regional Regulation Number 10 of 2015 concerning Changes in the Regional Revenue and Expenditure Budget for the 2015 Fiscal Year.

30. Bogor City Regional Regulation Number 6 of 2016 concerning Corporate Social and Environmental Responsibility.

31. Bogor City Regional Regulation Number 7 of 2016 concerning the Establishment and Structure of Bogor City Regional Apparatus.

32. Bogor City Regional Regulation Number 3 of 2016 concerning the Establishment of Regional Legal Products.

33. Bogor City Regional Regulation Number 4 of 2016 concerning Prevention and Control of Human Immunodeficiency Virus and Acquired Immune Deficiency Syndrome.

34. Bogor City Regional Regulation Number 1 Year 2016 concerning Regional Revenue and Expenditure Budget for Fiscal Year 2016. 
35. Bogor City Regional Regulation Number 2 of 2016 concerning Regional Equity Participation to Regional Companies Rural Bank Bank Pasar Bogor City.

36. Bogor City Regional Regulation Number 5 of 2016 concerning Accountability for the Implementation of the Regional Revenue and Expenditure Budget for the 2015 Fiscal Year.

37. Bogor City Regional Regulation Number 8 of 2016 concerning Changes in the Regional Revenue and Expenditure Budget for Fiscal Year 2016 concerning Changes in the Regional Revenue and Expenditure Budget for Fiscal Year 2016.

38. Bogor City Regional Regulation Number 9 of 2016 concerning the Master Plan for Regional Tourism Development for 2016-2025.

39. Bogor City Regional Regulation Number 8 of 2017 concerning the Implementation of Regional Government Affairs.

40. Bogor City Regional Regulation Number 4 of 2017 concerning Prevention and Quality Improvement of Slum Housing and Slum Settlements.

41. Bogor City Regional Regulation Number 2 of 2017 concerning Amendments to Regional Regulation Number 5 of 2011 concerning Street Lighting Tax.

42. Bogor City Regional Regulation Number 6 of 2017 concerning the Fourth Amendment to Bogor City Regional Regulation Number 15 of 2004 concerning Protocol and Financial Positions for Leaders and Members of the Bogor City Regional House of Representatives.

43. Bogor City Regional Regulation Number 3 of 2017 concerning the Implementation of Child Friendly Cities.

44. Bogor City Regional Regulation Number 5 of 2017 concerning Regional Public Company Rural Banks, Bogor City Bank.

45. Bogor City Regional Regulation Number 1 of 2018 concerning the Implementation of Disaster Management. 
46. Bogor City Regional Regulation Number 9 of 2018 concerning the Implementation of Informatics and Communication.

47. Bogor City Regional Regulation Number 4 of 2018 concerning Domestic Wastewater Management.

48. Bogor City Regional Regulation Number 2 of 2018 concerning Management of Regional Property.

49. Bogor City Regional Regulation Number 3 of 2018 concerning the Second Amendment to Bogor City Regional Regulation Number 16 of 2008 concerning the Implementation of Population Administration.

50. Bogor City Regional Regulation Number 5 of 2018 concerning Amendments to Bogor City Regional Regulation Number 2 of 2012 concerning Rural and Urban Land and Building Taxes.

51. Bogor City Regional Regulation Number 6 of 2018 concerning the Second Amendment to Bogor City Regional Regulation Number 4 of 2012 concerning Public Service Retribution.

52. Bogor City Regional Regulation Number 10 of 2018 concerning Amendments to Regional Regulation Number 12 of 2009 concerning Non-Smoking Areas.

53. Bogor City Regional Regulation Number 11 of 2018 concerning Health Implementation

54. Bogor City Regional Regulation Number 7 Regarding Accountability for Implementation of the Regional Revenue and Expenditure Budget for the 2017 Fiscal Year. From the list of Regional Regulations above, we can understand that the Bogor City Regional Regulations are quite complete covering various aspects of life. Starting from Regional Regulations related to environmental security, development, health, taxes, Domestic Wastewater Management, disaster management, Management and Implementation of Education, Information and Communication Management, Quality Improvement of Slum Housing and Slums, to Regional Regulations concerning Accountability for Implementation of the Revenue Budget, and Regional Shopping. Regional 
regulations produced by the DPRD are also more in the interests of the wider community. This shows that the legislative function carried out by the Bogor City DPRD is quite good.

\section{CONCLUSION}

The legislative function carried out by the Bogor City DPRD is in accordance with Law Number 23 of 2014 concerning Regional Government, one of which is to capture the aspirations of the people in Bogor City. By receiving reports or complaints from the people of Bogor City regarding problems with dissatisfaction with a service. Although the implementation is still not optimal because there are still obstacles in carrying out legislation.

\section{REFERENCES:}

Ali, Zainudin, Metode Penelitian Hukum, (Jakarta, Sinar Grafika: 2010).

Ashiddiqie, Jimly, Menuju Negara Hukum yang Demokratis, (Jakarta: PT. Buana Ilmu Populer, 1999).

Bogorkab.bps.go.id,

https://bogorkab.bps.go.id/statictable/2017/05/18/9/jumla

h-penduduk-kabupaten-bogor-menurut-kecamatan-

.html. Diunduh pada tanggal 24 Januari 2020 jam 18:31

Moenta (Andi), Pangerang. Syafa'at, Anugrah Pradana, Pokokpokok hukum pemerintahan daerah, (Jakarta, PT Raja Grafindo Persada: 2018).

Prakoso, Djoko, Proses Pembuatan Peraturan Daerah dan Beberapa Usaha Penyempurnaannya, (Jakarta, Ghalia Indonesia: 1995).

Sekretariat DPRD Kabupaten Bogor. http://setwan.bogorkab.go.id/visi-dan-misi/. Diunduh pada tanggal 1 Maret 2020 jam 19:11 
Suandi, Edi. Hamid. Malian Sobirin, Memperkokoh Otonomi Daerah, (Yogyakarta, UII Press: 2004).

Undang-Undang Dasar Negara Republik Indonesia Tahun 1945 Pasal 18 ayat (2).

Undang-Undang No. 32 Tahun 2004 tentang Pemerintahan Daerah.

Undang-Undang Nomor 23 Tahun 2014 Pasal 1 butir (4) tentang Pemerintahan Daerah.

Undang-Undang Nomor 23 Tahun 2014 pasal 106 ayat (1)Tentang Pemerintahan Daerah.

Undang-Undang Nomor 23 Tahun 2014 Pasal 149 ayat (1) tentang Fungsi DPRD Kabupaten/Kota.

Undang-Undang Nomor 9 Tahun 2015 pasal 101 ayat (1) Tentang Perubahan Kedua Atas Undang- Undang Nomor 23 tahun 2014 Tentang Pemerintahan Daerah.

Undang-Undang Nomor 9 Tahun 2015 pasal 154 ayat (1) Tentang Perubahan Kedua Atas Undang-Undang Nomor 23 tahun 2014 Tentang Pemerintahan Daerah.

Utang Rosidin, Otonomi Daerah dan Desentralisasi, (Jakarta: Pustaka Setia, 2009).

Waistiono, Sadu, Yonata Wiyoso, Meningkatkan Kinerja Dewan Perwakilan Rakyat Daerah (DPRD), (Bandung, Fokusmedia: 2010). 